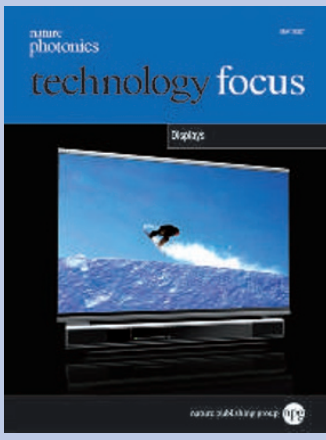

Cover image MicroDisplay's largescreen, high-definition, liquid-crystal-on-silicon television.

Business News p278

EDITOR: OLIVER GRAYDON

ASSOCIATE EDITORS: DAVID GEVAUX, AMBER JENKINS, RACHEL PEI CHIN WON

PRODUCTION EDITORS: SIMON GERRARD, CHRIS GILLOCH

COPY EDITOR: ANNA DEMMING

ART EDITOR: KAREN MOORE

\title{
On display
}

W elcome to our third Technology Focus installment. This month we are venturing into the world of displays, an industry that is set to bring in revenues of more than $\$ 100$ billion dollars this year.

The invention of the cathode-ray tube by Karl Ferdinand Braun in 1897 marked the dawn of a new era: television. Who would have guessed that the concept of generating images by firing electrons at a fluorescent screen could have such an impact on the world? Televisions have come a long way since their first appearance and the cathode-ray tube's 80-year reign has come to an end. Flat panels have done away with the need for bulky glass screens, and a variety of imaging technologies are fighting it out: plasma screens, LCDs, digital-light-processing projectors, organic LEDs, and others.

As Paul Semenza tells us in our Market Analysis article on page 267, the thin-filmtransistor LCD is now king of the jungle.

Dedicated investment in manufacturing has pushed costs down so that 50 -inch or larger, flat-screen, high-definition televisions are now a relatively common sight in people's homes. The drive for thin-film-transistor LCDs has also fuelled the expansion of the laptop-computer and desktop-monitor markets. But this dominance is being challenged. On page 273, Ken Dean of Motorola describes how carbon-nanotube-based displays could be the next big thing. He tells us that these tiny structures are the "best electron emitters that anyone could have imagined". Laser television will also be another one to watch. In our interview with Novalux on page 280, we learn that plasma displays and LCDs may have to make room for laser-based displays and the superior colour definition they offer.

Of course, it's not all about television. In another of our Industry Perspectives (page 276), we hear the story of liquid crystal on silicon, a new type of microdisplay that could find application in digital cameras, handheld devices and headmounted displays. The struggle for liquid crystal on silicon to become a mainstream technology highlights just how competitive the display arena is. The struggle for survival goes on, but whoever wins, displays will surely continue to change the world in new and unexpected ways.
MARKET ANALYSIS

267 Can anything catch TFT LCDs?

Paul Semenza

\section{RESEARCH HIGHLIGHTS}

$271 \quad$ High-performance backlight unit, carbon-nanotube displays, and more

\section{INDUSTRY PERSPECTIVE} A new era: Nanotube displays Kenneth A. Dean

276

A technology rollercoaster: Liquid crystal on silicon Mary Lou Jepson

\section{BUSINESS NEWS}

\section{8}

Funding for organic-LED technology, patent disputes, and more

\section{PRODUCT HIGHLIGHTS}

\section{9}

Sharp's 108-inch LCD television, a 10,000-lumen projector from Panasonic, and more

\section{INTERVIEW}

